\title{
Abdominal Aortic Screening Is a Priority for Health in Smoker Males: A Study on Central Italian Population
}

\author{
Emma Altobelli ${ }^{1, *}$, Filippo Gianfelice ${ }^{2}$, Paolo Matteo Angeletti ${ }^{1,3}$ and Reimondo Petrocelli ${ }^{4}$ \\ 1 Department of Life, Public Health and Environmental Sciences, University of L'Aquila, 67100 L'Aquila, Italy; \\ paolomatteoangeletti@gmail.com \\ 2 Vascular Surgery, G. Mazzini di Teramo Hospital, Local Health Unit, 64100 Teramo, Italy; \\ filippo.gianfelice@virgilio.it \\ 3 Rianimazione e TIPO Cardiochirurgica, Ospedale G. Mazzini, Local Health Unit, 64100 Teramo, Italy \\ 4 S. Timoteo Hospital, ASREM, 86100 Campobasso, Italy; r.petrocelli@libero.it \\ * Correspondence: emma.altobelli@univaq.it; Tel.: +39-0862-434666; Fax: +39-0862-432903
}

check for updates

Citation: Altobelli, E.; Gianfelice, F.; Angeletti, P.M.; Petrocelli, R. Abdominal Aortic Screening Is a Priority for Health in Smoker Males: A Study on Central Italian Population. Int. J. Environ. Res. Public Health 2022, 19, 591. https://doi.org/ 10.3390/ijerph19010591

Academic Editor: Giuseppe Biondi Zoccai

Received: 22 December 2021

Accepted: 2 January 2022

Published: 5 January 2022

Publisher's Note: MDPI stays neutral with regard to jurisdictional claims in published maps and institutional affiliations.

Copyright: (C) 2022 by the authors. Licensee MDPI, Basel, Switzerland. This article is an open access article distributed under the terms and conditions of the Creative Commons Attribution (CC BY) license (https:// creativecommons.org/licenses/by/ $4.0 /)$.

\begin{abstract}
Abdominal aortic aneurysm (AAA) is a major public health problem. In the last decade, in some European countries, abdominal aortic screening (AAS) is emerging as a potential prevention for the rupture of AAA. The goals of our study were to estimate AAA prevalence and risk factors in males and females in a central Italian population, also defining the cost-effectiveness of AAS programs. A pilot study screening was conducted between 1 January 2015 and 31 December 2019 in the municipality of Teramo (Abruzzo Region, Italy) in a group of men and women, ranging from the age of 65 to 79, who were not previously operated on for AAA. The ultrasound was performed by means of Acuson sequoia 512 Simens with a Convex probe. The anterior posterior of the infra-renal aorta was evaluated. The odds ratio values (ORs) were used to evaluate the risk of AAA, and the following determinants were taken into consideration: gender, smoke use, hypertension, and ischemic heart disease. We also estimated the direct costs coming from aneurysmectomy (surgical repair or endovascular aneurysms repair-EVAR). A total of 62 AAA $(2.7 \%$, mean age $73.8 \pm 4.0)$ were diagnosed, of which 57 were in men $(3.7 \%$, mean age $73.6 \pm 4.0)$ and 5 were in women $(0.7 \%$, mean age $74.3 \pm 4.1)$. Male gender and smoke use are more important risk factors for AAA $\geq 3 \mathrm{~cm}$, respectively: $\mathrm{OR}=5.94(2.37-14.99, p<0.001)$ and $\mathrm{OR}=5.21(2.63-10.30, p<0.000)$. A significant increase in OR was noted for AAA $\geq 3 \mathrm{~cm}$ and cardiac arrhythmia and ischemic heart disease, respectively: $\mathrm{OR}=2.81(1.53-5.15, p<0.000)$ and $\mathrm{OR}=2.76(1.40-5.43, p=0.006)$. Regarding the cost analysis, it appears that screening has contributed to the reduction in costs related to urgency. In fact, the synthetic indicator given by the ratio between the DRGs (disease related group) relating to the emergency and those of the elective activity went from 1.69 in the year prior to the activation of the screening to a median of 0.39 for the five-year period of activation of the screening. It is important to underline that the results of our work confirm that the screening activated in our territory has led to a reduction in the expenditure for AAA emergency interventions, having increased the planned interventions. This must be a warning for local stakeholders, especially in the post-pandemic period, in order to strengthen prevention.
\end{abstract}

Keywords: abdominal aortic aneurysm; prevalence; screening; risk factors and cost-effectiveness

\section{Introduction}

Abdominal aortic aneurysm (AAA) is a major public health problem. It consists of a dilation of the $\mathrm{AAA} \geq 3 \mathrm{~cm}$ [1] that, in $85 \%$ of cases, occurs in the infra-renal segment of the abdominal aorta [2].

AAA prevalence rates have decreased in the last decades from 7.2 to 3.9 [3,4]; currently, AAA has a range between $1.2 \%$ and $3.3 \%[5,6]$.

Recent data show that the risk of rupture is 3.5\% for a diameter between 5.5 and $6 \mathrm{~cm}$, $4.1 \%$ between 6.1 and $7 \mathrm{~cm}$, and $6.3 \%$ if $\geq 7 \mathrm{~cm}$ [7]. The real danger of the AAA consists in the 
fact that it is often asymptomatic until its rupture, causing mortality in 60-80\% of cases [8]. In fact, an important proportion of patients die before they arrive in the operating room [9]. On the other hand, if the surgical correction is made with an intervention schedule, there is an important reduction in mortality of between 2 and 4\% [10]. The ultrasound is diagnostic if conducted by expert personnel, with a sensitivity of $95 \%$ and a specificity of $100 \%$ [9]. The Preventive Service Task Force recommends AAA screening by ultrasonography in men aged 65 to 75 years who have smoked, but not among non-smokers [11]. In fact, the AAA prevalence is four times higher in smokers than in non-smokers [12]. Ahmed et al. reported that patients with AAA were often smoker males [13]. Regarding cardiovascular diseases, smoking was found to be the major risk factor associated with AAA [14].

It is important to underline that the growth rate of aneurysms is higher in smokers [15]. Among younger patients, a higher frequency was found in subjects with high cardiovascular risk [16].

However, although important systematic reviews and meta-analysis effectiveness of this screening has been demonstrated [17-19], it has not been implemented in all developed countries yet, perhaps due to a lack of dedicated economic resources. AAA screening programs have been set up in the UK, Sweden, and the USA [20]. These programs use ultrasonography to screen AAA with a dilation of the AAA $\geq 3 \mathrm{~cm}$, and they examine men of $\geq 65$ years. Recently, AAA prevalence was evaluated in a Northern Italian population recruiting subjects younger than 65 years, including women [16].

The aims of our study were: (1) to estimate AAA prevalence and risk factors in males and females in a Central Italian population; (2) to define the cost-effectiveness of AAA screening programs.

\section{Materials and Methods}

To estimate the sampling dimension $(n=4035)$ the following parameters were used: sample error $\mathrm{E}=1.99$ and 1-alpha $=0.95$.

Our study was a prospective study conducted between 1 January 2015 and 31 December 2019 in the municipality of Teramo (Abruzzo Region, Italy).

Inclusion criteria were: (1) men and women ranging from the age of 65 to 79 ; (2) who were not previously operated on for AAA.

Population-group target residents in Teramo, on 1 January 2015, consisted of 466,700 citizens, of which there were 22,048 males and 24,622 females. The citizen was contacted by a letter explaining the scope of the screening and diagnostic test involved; it was followed up by a telephone call a few days before the appointment (Figure 1 flow chart). The citizens that accepted signed a consent form and were asked to fill in a questionnaire that contained socio-demographic and anamnestic variables. The coverage of screening was $57 \%$.

The ultrasound was performed by means of Acuson Sequoia 512 Simens with a Convex probe. The anterior posterior of the infra-renal aorta was evaluated.

In our study, the association between the presence of aortic aneurysm and anamnestic determinants were evaluated by Chi-square test or Fisher's exact test, when appropriate. $Z$ test for the equality of two proportions was used to verify the differences between gender in AAA diagnosed. The quantitative data were described as a mean \pm standard deviation (SD). The odds ratio values (ORs) were used to evaluate the risk of AAA and the determinants taken into consideration.

All analyses were conducted using the software SAS/STAT.

Finally, we estimated the direct costs derived from aneurysmectomy (surgical repair or endovascular aneurysm repair-EVAR) performed in an emergency at Mazzini Hospital in the ordinary regime. The costs were taken from the tariff set by the Abruzzo region [21]. 




Figure 1. Study flowchart.

\section{Results}

In the study period, 2749 males and 1286 females were contacted; 2301 (57\%) accepted, of which 1529 were males (55.6\%, mean age $73.6 \pm 4.0)$ and 772 were females $(60 \%$, mean age $74.3 \pm 4.1)$. A total of 62 AAA $(2.7 \%$, mean age $73.8 \pm 4.0)$ were diagnosed, of which 57 were in men $(3.7 \%$, mean age $73.6 \pm 4.0)$ and 5 were in women $(0.7 \%$, mean age $74.3 \pm 4.1)$. All responders were retirees.

The socio-demographic and comorbidity of responders are summarized in Tables 1 and 2 and Figures 2 and 3. Concerning the marital status and education variables, the percentage of primary school and widows was higher in females than in males, $p<0.000$ and $p=0.009$, respectively. Smoke use, hypertension, and ischemic heart disease were more frequent in males than females, respectively: $62.8 \%, 64.2 \%$, and $10.0 \%(p<0.000)$. No statistically significant difference for arrhythmia between gender was found.

Table 1. Socio-demographic variables.

\begin{tabular}{|c|c|c|c|c|}
\hline \multirow[t]{2}{*}{ Variables } & \multirow[t]{2}{*}{ Responders } & \multicolumn{2}{|c|}{ Gender } & \multirow[b]{2}{*}{$p$-Values } \\
\hline & & $\begin{array}{l}\text { No. }(\%) \\
\text { Males }\end{array}$ & $\begin{array}{l}\text { No. (\%) } \\
\text { Females }\end{array}$ & \\
\hline \multicolumn{4}{|c|}{ Marital status } & \multirow{6}{*}{$\begin{array}{c}<0.000 \\
X^{2}=263.4\end{array}$} \\
\hline Unmarried & 92 & $59(4.3)$ & $33(4.8)$ & \\
\hline Married & 1684 & $1241(89.7)$ & $443(64.4)$ & \\
\hline Divorced & 27 & $20(1.3)$ & $7(1.0)$ & \\
\hline Widow/er & 268 & $63(4.7)$ & $205(27.8)$ & \\
\hline Total responders & 2071 & 1383 & 688 & \\
\hline \multicolumn{4}{|c|}{ Education } & \multirow{9}{*}{$\begin{array}{c}0.009 \\
X^{2}=18.7\end{array}$} \\
\hline Illiterate & 3 & $2(0.1)$ & $1(0.1)$ & \\
\hline Primary school & 1188 & $769(55.6)$ & $419(61.0)$ & \\
\hline Middle school & 333 & $236(17.1)$ & $97(14.1)$ & \\
\hline Some years of high school & 190 & $148(10.7)$ & $42(6.1)$ & \\
\hline Professional school or some years of university & 211 & $131(9.5)$ & $80(11.6)$ & \\
\hline Degree & 146 & $97(7.0)$ & $49(7.1)$ & \\
\hline Master's degree & 1 & $1(0.1)$ & $0(0.0)$ & \\
\hline Total responders & 2072 & 1384 & 688 & \\
\hline
\end{tabular}


Table 2. Comorbidity distribution according to gender.

\begin{tabular}{|c|c|c|c|c|}
\hline Gender & Responders & $\begin{array}{c}\text { No. }(\%) \\
\text { Yes }\end{array}$ & $\begin{array}{c}\text { No. (\%) } \\
\text { Not }\end{array}$ & $p$-Values \\
\hline \multicolumn{5}{|c|}{ Smoke Use } \\
\hline Males & 1523 & $956(62.8)$ & $567(37.2)$ & \multirow{3}{*}{$\begin{array}{c}<0.000 \\
X^{2}=256.7\end{array}$} \\
\hline Females & 771 & $211(27.4)$ & $560(72.6)$ & \\
\hline Total responders & 2294 & 1167 & 1127 & \\
\hline \multicolumn{5}{|c|}{ Hypertension } \\
\hline & & No. (\%) Yes & No. (\%) Not & \multirow{4}{*}{$\begin{array}{c}<0.000 \\
X^{2}=12.3\end{array}$} \\
\hline Males & 1380 & $886(64.2)$ & $494(35.8)$ & \\
\hline Females & 684 & $492(71.9)$ & $192(28.1)$ & \\
\hline Total responders & 2064 & 1378 & 686 & \\
\hline \multicolumn{4}{|c|}{ Arrhythmia } & \multirow{5}{*}{$\begin{array}{c}0.3 \\
X^{2}=1.1\end{array}$} \\
\hline & & No. (\%) Yes & No. (\%) Not & \\
\hline Males & 1378 & $154(11.2)$ & $1224(88.8)$ & \\
\hline Females & 684 & $87(12.7)$ & $597(87.3)$ & \\
\hline Total responders & 2062 & 241 & 1821 & \\
\hline \multicolumn{4}{|c|}{ Ischemic heart disease } & \multirow{5}{*}{$\begin{array}{c}<0.000 \\
X^{2}=16.2\end{array}$} \\
\hline & & No. (\%) Yes & No. (\%) Not & \\
\hline Males & 1379 & $138(10.0)$ & $1241(90.0)$ & \\
\hline Females & 684 & $33(4.8)$ & $651(95.2)$ & \\
\hline Total responders & 2063 & 171 & 1892 & \\
\hline
\end{tabular}



Female $₫$ Male

Figure 2. Distribution of socio-demographic variables.

The associations among $\mathrm{AAA} \geq 3 \mathrm{~cm}$ and the determinants taken into account are reported in Table 3. 


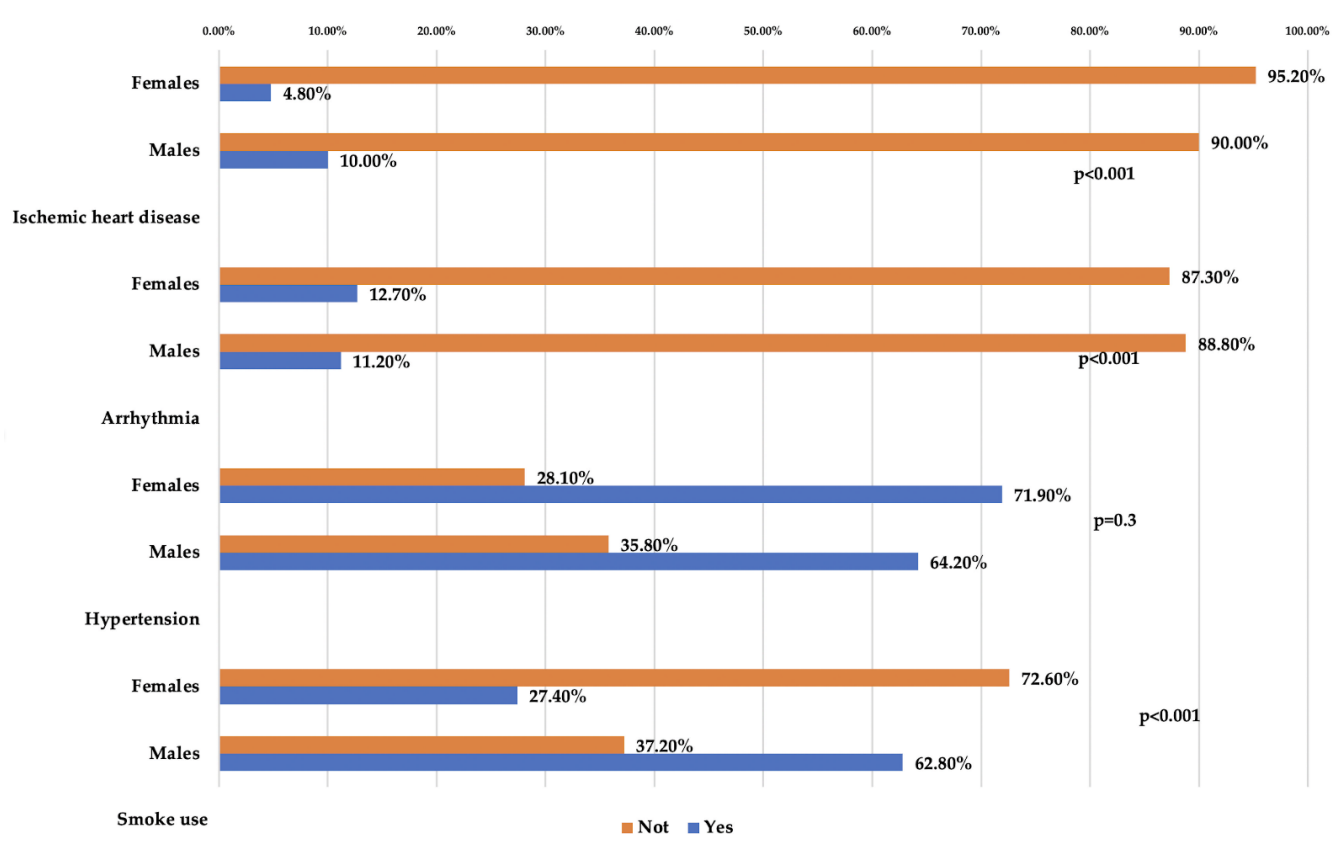

Figure 3. Distribution of comorbidity according to gender.

Table 3. Association and risk factors of AAA according to variables considered.

\begin{tabular}{|c|c|c|c|c|}
\hline \multicolumn{5}{|c|}{ Gender and Abdominal Aortic Diameter } \\
\hline \multicolumn{5}{|c|}{ Diameter } \\
\hline Gender & No. $(\%)<3 \mathrm{~cm}$ & No. $(\%) \geq 3 \mathrm{~cm}$ & Total & \multirow{4}{*}{$\begin{array}{c}X^{2}=18.6 \\
p \leq 0.000 \\
\text { OR: } 5.94 \\
(2.37-14.88)\end{array}$} \\
\hline Males & $1472(96.3)$ & $57(3.7)$ & 1529 & \\
\hline Females & $767(99.4)$ & $5(0.6)$ & 772 & \\
\hline Total & 2239 & 62 & 2301 & \\
\hline \multicolumn{5}{|c|}{ Current smokers or former smokers ( $\geq 10$ cigarettes/day) } \\
\hline \multicolumn{5}{|c|}{ Diameter } \\
\hline Smoke use & No. $(\%)<3 \mathrm{~cm}$ & No. $(\%) \geq 3 \mathrm{~cm}$ & Total & \multirow{4}{*}{$\begin{array}{c}X^{2}=27.8 \\
p \leq 0.000 \\
\text { OR: } 5.21 \\
(2.63-10.30)\end{array}$} \\
\hline Yes & $1115(95.5)$ & $52(4.5)$ & 1167 & \\
\hline Not & $1117(99.1)$ & $10(0.9)$ & 1127 & \\
\hline Total responders & 2232 & 62 & 2294 & \\
\hline \multicolumn{5}{|c|}{ Cardiac arrhythmia and abdominal aortic diameter } \\
\hline \multicolumn{5}{|c|}{ Diameter } \\
\hline Arhythmia & No. $(\%)<3 \mathrm{~cm}$ & No. $(\%) \geq 3 \mathrm{~cm}$ & Total & \multirow{4}{*}{$\begin{array}{c}X^{2}=12.8 \\
p \leq 0.000 \\
\text { OR: } 2.81 \\
(1.53-5.15)\end{array}$} \\
\hline Yes & $226(93.8)$ & $15(6.2)$ & 241 & \\
\hline Not & $1779(99.1)$ & $42(2.3)$ & 1821 & \\
\hline Total responders & 2005 & 57 & 2062 & \\
\hline \multicolumn{5}{|c|}{ Ischemic heart disease and abdominal aortic diameter } \\
\hline \multicolumn{5}{|c|}{ Diameter } \\
\hline Ischemic heart disease & No. $(\%)<3 \mathrm{~cm}$ & No. $(\%) \geq 3 \mathrm{~cm}$ & Total & \multirow{4}{*}{$\begin{array}{c}X^{2}=27.8 \\
p=0.006 \\
\text { OR: } 2.76 \\
(1.40-5.43)\end{array}$} \\
\hline Yes & $160(96.3)$ & $11(6.4)$ & 171 & \\
\hline Not & $1846(97.6)$ & $46(2.4)$ & 1892 & \\
\hline Total responders & 2006 & 57 & 2063 & \\
\hline \multicolumn{5}{|c|}{ Hypertension and abdominal aortic diameter } \\
\hline \multicolumn{5}{|c|}{ Diameter } \\
\hline Hypertension & No. $(\%)<3 \mathrm{~cm}$ & No. $(\%) \geq 3 \mathrm{~cm}$ & Total & \multirow{4}{*}{$\begin{array}{c}X^{2}=2.1 \\
p=0.149 \\
\text { OR: } 0.68 \\
(0.40-1.15)\end{array}$} \\
\hline Yes & 1345 (97.6) & $33(2.4)$ & 1378 & \\
\hline Not & $662(96.5)$ & $24(3.5)$ & 686 & \\
\hline Total responders & 2007 & 57 & & \\
\hline
\end{tabular}


It is important to underline that male gender and smoke use are more important risk factors for AAA $\geq 3 \mathrm{~cm}$, respectively: OR = $5.94(2.37-14.99 p<0.001)$ and $\mathrm{OR}=5.21$ $(2.63-10.30, p<0.000)$.

A significant increase in OR was noted for AAA $\geq 3 \mathrm{~cm}$ and cardiac arrhythmia and ischemic heart disease, respectively: $\mathrm{OR}=2.81(1.53-5.15, p<0.000)$ and $\mathrm{OR}=2.76$ $(1.40-5.43, p=0.006)$.

Table 4 shows the surgical interventions for AAA in an emergency due to rupture and planned. In the year preceding the activation of the screening, a total of 20 emergency interventions for aneurysm rupture were observed, compared to 16 scheduled interventions. Starting from the following year, there were 6 emergency interventions against 21 in election, a trend confirmed in the following years of screening (Table 4).

Table 4. Screening according to surgery and costs.

\begin{tabular}{|c|c|c|c|c|c|c|c|c|c|c|c|c|}
\hline & \multicolumn{4}{|c|}{ Emergency } & \multicolumn{4}{|c|}{ Planned } & \multirow{2}{*}{$\begin{array}{c}\text { Costs of } \\
\text { Emergency } \\
\text { Euro }\end{array}$} & \multirow{2}{*}{$\begin{array}{c}\text { Costs } \\
\text { Planned } \\
\text { Euro }\end{array}$} & \multirow{2}{*}{$\begin{array}{c}\text { Screening } \\
\text { Coasts/Year } \\
\text { Euro }\end{array}$} & \multirow{2}{*}{$\begin{array}{c}\text { Ratio } \\
\text { Emergency } \\
\text { Planned }\end{array}$} \\
\hline & Evar & Open & TOT & $\begin{array}{c}\text { Costs } \\
\text { Drg } 110 \\
\text { Euro }\end{array}$ & Evar & Open & Tot & $\begin{array}{c}\text { Costs } \\
\text { DRG } 111 \\
\text { Euro }\end{array}$ & & & & \\
\hline 2014 & 4 & 16 & 20 & $13,874.36$ & & & 16 & $10,253.09$ & $277,487.20$ & $164,049.44$ & Inactive screening & 1.69 \\
\hline 2015 & 2 & 4 & 6 & & & & 21 & & $83,246.16$ & $215,314.89$ & $14,726.40$ & 0.39 \\
\hline 2016 & 2 & 8 & 10 & & & & 20 & & $138,743.60$ & $205,061.80$ & $14,726.40$ & 0.68 \\
\hline 2017 & 1 & 0 & 1 & & 12 & 7 & 19 & & $13,874.36$ & $194,808.71$ & $14,726.40$ & 0.07 \\
\hline 2018 & 0 & 0 & 0 & & 8 & 3 & 11 & & - & $112,783.99$ & $14,726.40$ & 0.00 \\
\hline \multirow[t]{2}{*}{2019} & 2 & 0 & 2 & & 6 & 1 & 7 & & $27,748.72$ & $71,771.63$ & $14,726.40$ & 0.39 \\
\hline & & & & & & & & & $541,100.04$ & $963,790.46$ & $73,632.00$ & 0.56 \\
\hline
\end{tabular}

DRG: DIAGNOSIS RELATED GROUPS. DRG 110: major intervention on cardiovascular system with complications EUR 13,874.36. DRG 111: major intervention on cardiovascular system without complications EUR 10,253.09.

Regarding cost analysis, it appears that screening has contributed to the reduction in costs related to urgency. In fact, the synthetic indicator given by the ratio between the DRGs (disease related group) relating to the emergency and those of the elective activity went from 1.69 in the year prior to the activation of the screening to a median of 0.39 for the five-year period of activation of the screening.

\section{Discussion}

The importance of screening campaigns is well known to diagnose a disease early, before the onset of symptoms, and to promptly initiate therapeutic treatment. An early treatment, in fact, has advantages over a late treatment, in terms of recovery, survival from the disease, and simpler treatments. In Italy and Europe, various screening campaigns have been active for many years against breast cancer [22], colorectal cancer [23], and cervical cancer [24]. The Italian National Health System guarantees uniform access throughout the territory to these programs [22].

In the last decade in some European countries [18], but also in other countries [13], abdominal aortic screening (AAS) is emerging as a potential prevention campaign; although, most of the initiatives are local and spontaneous. On the other hand, in the UK, AAS is structured as a population-based screening $[25,26]$.

It has been shown that the risk of rupture of the aneurysm in males is directly correlated with the diameter, so early diagnosis can become a lifesaver [18].

In our population-based study, the prevalence was $2.7 \%$, similar to that reported in the literature [27]. The stratification by gender shows values higher in men (3.8\%), with a risk equal to 5.94 , than in women $(0.65 \%)$.

Another interesting aspect that confirms the literature was the higher prevalence of AAA in smokers (4.67\%) compared to non-smokers $(0.89 \%)$. Smoke use is an important risk factor determining an $\mathrm{OR}=5.21$. A similar result was found by Ahmed et al. [13]. The mechanisms by which smoking predisposes to a greater tendency to aneurysm are 
not fully clarified. A recent paper from Carnevale et al. underlines the importance of addressing screening campaigns in smokers under 65 years and in non-smoking men over 70 [26]. Sweeting et al. [27] showed that the annual growth of an aneurysm in the smoker is $0.35 \mathrm{~mm}$ /year higher than that found in the general population, $2.21 \mathrm{~mm} /$ year. This increase is probably due to many factors, such as inflammatory structure, metabolic causes, and others [28]. Recent work on the animal model has shown that smoking contributes to tissue inflammation and apoptosis of vascular smooth muscle cells [29]. The same inflammatory mechanism would be contributing to ischemic heart disease [30]. This evidence could support the increased risk of AAA in smokers and those with a history of ischemic heart disease. Regarding the latter, the results of our study show that AAA is associated with ischemic heart disease $(p=0.006)$ with an $\mathrm{OR}=2.76$.

Therefore, identifying risk factors becomes crucial when it comes to clinical practice. Especially in light of the limited economic resources that, as Cochrane stated, should be used for health interventions, the effectiveness of which has been proven [31].

Giardinia et al. [32], in a study conducted on the Italian population, showed that abdominal aortic screening is cost-effective. This evidence also results from a recent metaanalysis by Ying et al. [33], which showed that screening reduces mortality. The mortality found for AAA in our area where screening was activated was $1.025 \%$; this result is lower than the national Figure 1.7\% (Figure 4) [34].

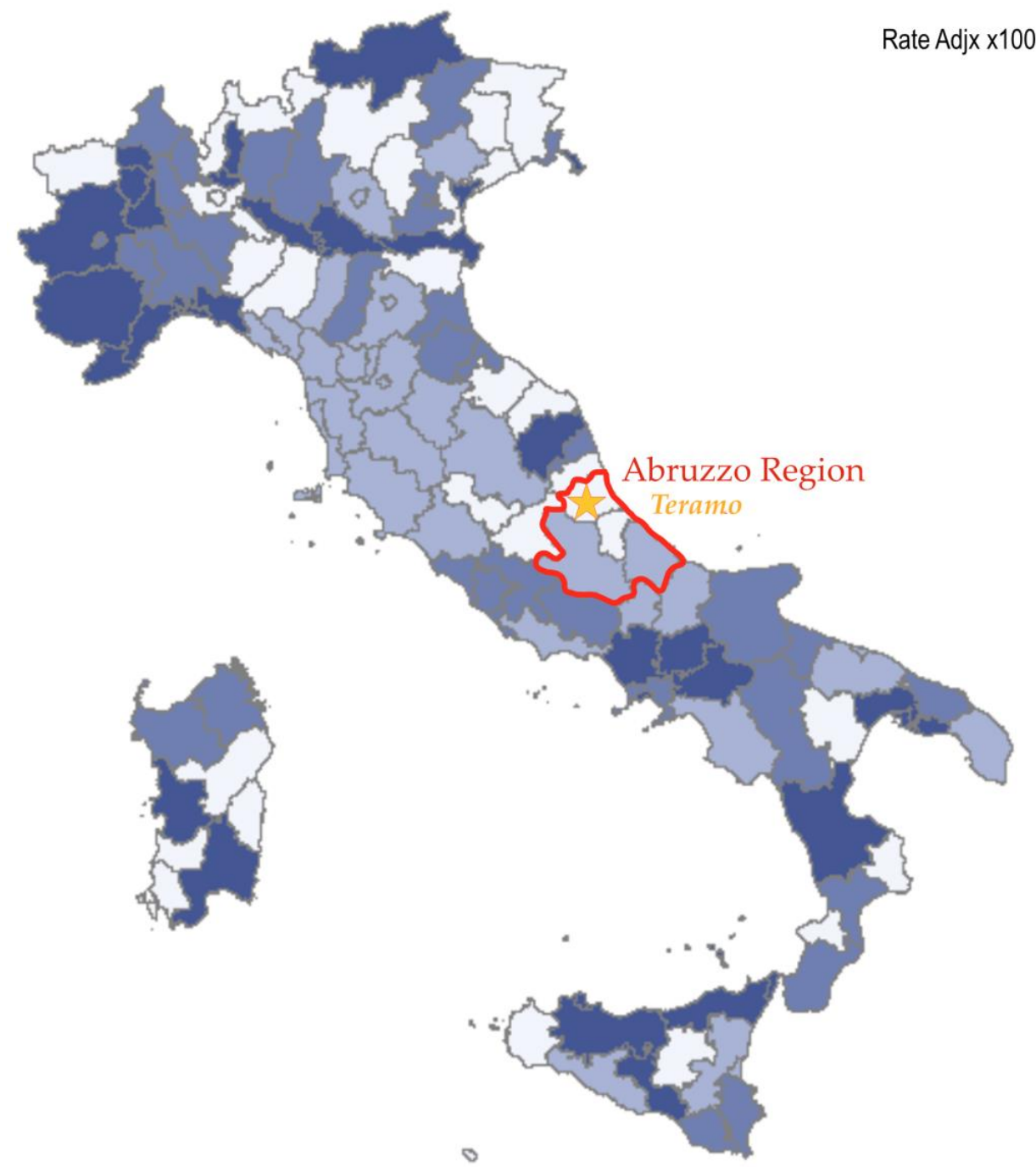

Figure 4. National and Regional death rate for non-ruptured AAA. The color gradient showed the incidence rate of AAA in each Italian province. 
A similar reduction in AAA mortality is present in the study by Ashton et al. [35] and confirmed by several meta-analyses. [11,33].

The results of our work confirm that the screening activated in our territory has led to a reduction in the expenditure for AAA emergency interventions, having increased the planned interventions (Table 3). It seems important to underline that simulation models highlight how the cost-benefit of this initiative is maintained even if applied in different national contexts [32,36].

This must be a warning for local stakeholders, especially in the post-pandemic period, to strengthen prevention. In particular, with regard to the AAA, an effort in terms of resource allocation could be addressed primarily to the screening of smoking patients and patients with ischemic heart disease (the latter easily identifiable on the basis of hospital records or pharmacological prescriptions). Wild et al. [37] showed that aortic dilations between $25 \mathrm{~mm}$ and $29 \mathrm{~mm}$, in $8.3 \%$ of cases, can evolve over 13.4 years to an aneurysm.

A decisive role could be played by family doctors in identifying high-risk patients, promoting their control through ultrasound screening, and making people aware of taking action on modifiable risk factors relating to lifestyles [38], with particular reference to smoking.

\title{
5. Conclusions
}

Screening for an abdominal aortic aneurysm is a useful investigation to reduce the specific mortality of this pathology. Furthermore, considering the high prevalence of AAA, the often-silent clinic and the high mortality related to its more fearful complication, rupture, a key role in early diagnosis, or at least in diagnostic suspicion, is played by the general practitioner (GP). In fact, GPs are well aware of their patients' lifestyles, such as the use of alcohol and smoking, which represent important risk factors. The GP, as part of the assessment of the patient, is, therefore, the first line in acknowledging or suspecting a potentially fatal condition. In addition, the ultrasound examination is suitable, due to its non-invasive characteristics and easy applicability, as a first exam level for the identification of the AAA, which can also be implemented in the suitably trained GP's medical office.

Author Contributions: Conceptualization, E.A.; methodology, E.A.; software, P.M.A.; validation, E.A. and P.M.A., R.P. and R.P.; formal analysis, E.A.; investigation, P.M.A., R.P. and F.G.; data curation, E.A. and P.M.A.; writing—original draft preparation, E.A., R.P., P.M.A. and F.G.; writing-review and editing, E.A.; project administration, E.A. All authors have read and agreed to the published version of the manuscript.

Funding: This work received no external funding.

Institutional Review Board Statement: Not applicable.

Informed Consent Statement: Not applicable.

Data Availability Statement: No data supporting.

Conflicts of Interest: The authors declare no conflict of interest.

\author{
Abbreviations \\ AAA Abdominal aortic aneurysm \\ DRG disease related group \\ EVAR Endovascular aneurysms repair
}

\section{References}

1. Moll, F.L.; Powell, J.T.; Fraedrich, G.; Verzini, F.; Haulon, S.; Waltham, M.; van Herwaarden, J.A.; Holt, P.J.E.; van Keulen, J.W.; Rantner, B.; et al. Management of Abdominal Aortic Aneurysms Clinical Practice Guidelines of the European Society for Vascular Surgery. Eur. J. Vasc. Endovasc. Surg. 2011, 41 (Suppl. 1), S1-S58. [CrossRef]

2. Jongkind, V.; Yeung, K.K.; Akkersdijk, G.J.; Heidsieck, D.; Reitsma, J.B.; Tangelder, G.J.; Wisselink, W. Juxtarenal aortic aneurysm repair. J. Vasc. Surg. 2010, 52, 760-767. [CrossRef] [PubMed] 
3. Lindholt, J.S.; Juul, S.; Fasting, H.; Henneberg, E.W. Screening for abdominal aortic aneurysms: Single centre randomised controlled trial. BMJ 2005, 330, 750. [CrossRef]

4. McCaul, K.A.; Lawrence-Brown, M.; Dickinson, J.A.; Norman, P.E. Long-term Outcomes of the Western Australian Trial of Screening for Abdominal Aortic Aneurysms: Secondary Analysis of a Randomized Clinical Trial. JAMA Intern. Med. 2016, 176, 1761-1767. [CrossRef] [PubMed]

5. Benson, R.A.; Poole, R.; Murray, S.; Moxey, P.; Loftus, I.M. Screening results from a large United Kingdom abdominal aortic aneurysm screening center in the context of optimizing United Kingdom National Abdominal Aortic Aneurysm Screening Programme protocols. J. Vasc. Surg. 2016, 63, 301-304. [CrossRef] [PubMed]

6. Grøndal, N.; Søgaard, R.; Lindholt, J. Baseline prevalence of abdominal aortic aneurysm, peripheral arterial disease and hypertension in men aged 65-74 years from a population screening study (VIVA trial). BJS 2015, 102, 902-906. [CrossRef]

7. Parkinson, F.; Ferguson, S.; Lewis, P.; Williams, I.M.; Twine, C.P. Rupture rates of untreated large abdominal aortic aneurysms in patients unfit for elective repair. J. Vasc. Surg. 2015, 61, 1606-1612. [CrossRef]

8. Kniemeyer, H.; Kessler, T.; Reber, P.; Ris, H.; Hakki, H.; Widmer, M. Treatment of Ruptured Abdominal Aortic Aneurysm, a Permanent Challenge or a Waste of Resources? Prediction of Outcome Using a Multi-organ-dysfunction Score. Eur. J. Vasc. Endovasc. Surg. 2000, 19, 190-196. [CrossRef]

9. Fleming, C.; Whitlock, E.P.; Beil, T.L.; Lederle, F.A. Screening for Abdominal Aortic Aneurysm: A Best-Evidence Systematic Review for the U.S. Preventive Services Task Force. Ann. Intern. Med. 2005, 142, 203-211. [CrossRef]

10. Dimick, J.B.; Cowan, J.A., Jr.; Stanley, J.C.; Henke, P.K.; Pronovost, P.J.; Upchurch, G.R., Jr. Surgeon specialty and provider volumes are related to outcome of intact abdominal aortic aneurysm repair in the United States. J. Vasc. Surg. 2003, 38, 739-744. [CrossRef]

11. Guirguis-Blake, J.M.; Beil, T.L.; Senger, C.A.; Whitlock, E.P. Ultrasonography Screening for Abdominal Aortic Aneurysms: A Systematic Evidence Review for the U.S. Preventive Services Task Force. Ann. Intern. Med. 2014, 160, 321-329. [CrossRef]

12. Corrado, G.; Durante, A.; Genchi, V.; Trabattoni, L.; Beretta, S.; Rovelli, E.; Foglia-Manzillo, G.; Ferrari, G. Prevalence of previously undiagnosed abdominal aortic aneurysms in the area of Como: The ComoCuore "looking for AAA" ultrasonography screening. Int. J. Cardiovasc. Imaging 2016, 32, 1213-1217. [CrossRef]

13. Shaker, A.A.; Khairy, H.M.; Elkaffas, K.H.; Ghanem, A.A. Frequency of abdominal aortic aneurysm in persons who have been examined with ultrasound at Kasr Al-Ainy Hospitals: A single center pilot study. Acta Angiol. 2019, 25, 133-139. [CrossRef]

14. Pujades-Rodriguez, M.; George, J.; Shah, A.D.; Rapsomaniki, E.; Denaxas, S.; West, R.; Smeeth, L.; Timmis, A.; Hemingway, H. Heterogeneous associations between smoking and a wide range of initial presentations of cardiovascular disease in 1937360 people in England: Lifetime risks and implications for risk prediction. Int. J. Epidemiol. 2015, 44, 129-141. [CrossRef] [PubMed]

15. Vazquez, C.; Sakalihasan, N.; D'Harcour, J.-B.; Limet, R. Routine Ultrasound Screening for Abdominal Aortic Aneurysm among 65- and 75-Year-Old Men in a City of 200,000 Inhabitants. Ann. Vasc. Surg. 1998, 12, 544-549. [CrossRef] [PubMed]

16. Gianfagna, F.; Veronesi, G.; Tozzi, M.; Tarallo, A.; Borchini, R.; Ferrario, M.M.; Bertù, L.; Montonati, A.; Castelli, P.; Mara, L.; et al. Prevalence of Abdominal Aortic Aneurysms in the General Population and in Subgroups at High Cardiovascular Risk in Italy. Results of the RoCAV Population Based Study. Eur. J. Vasc. Endovasc. Surg. 2018, 55, 633-639. [CrossRef]

17. Cornuz, J.; Pinto, C.S.; Tevaearai, H.; Egger, M. Risk factors for asymptomatic abdominal aortic aneurysm: Systematic review and meta-analysis of population-based screening studies. Eur. J. Public Health 2004, 14, 343-349. [CrossRef]

18. Altobelli, E.; Rapacchietta, L.; Profeta, V.F.; Fagnano, R. Risk Factors for Abdominal Aortic Aneurysm in Population-Based Studies: A Systematic Review and Meta-Analysis. Int. J. Environ. Res. Public Health 2018, 15, 2805. [CrossRef] [PubMed]

19. Ali, M.U.; Fitzpatrick-Lewis, D.; Kenny, M.; Miller, J.; Raina, P.; Sherifali, D. A systematic review of short-term vs long-term effectiveness of one-time abdominal aortic aneurysm screening in men with ultrasound. J. Vasc. Surg. 2018, 68, 612-623. [CrossRef] [PubMed]

20. A Benson, R.; Meecham, L.; Fisher, O.; Loftus, I.M. Ultrasound screening for abdominal aortic aneurysm: Current practice, challenges and controversies. Br. J. Radiol. 2018, 91, 20170306. [CrossRef] [PubMed]

21. Bollettino Ufficiale Regione Abruzzo, Decreto Tariffe Ospedaliere. Available online: https://www.regione.abruzzo.it/system/ files/dgr/2017/DGR305_2017.pdf (accessed on 22 October 2021).

22. Altobelli, E.; Rapacchietta, L.; Angeletti, P.M.; Barbante, L.; Profeta, F.V.; Fagnano, R. Breast Cancer Screening Programmes across the WHO European Region: Differences among Countries Based on National Income Level. Int. J. Environ. Res. Public Health 2017, 14, 452. [CrossRef]

23. Altobelli, E.; Rapacchietta, L.; Marziliano, C.; Campagna, G.; Profeta, V.F.; Fagnano, R. Differences in colorectal cancer surveillance epidemiology and screening in the WHO European Region. Oncol. Lett. 2018, 17, 2531-2542. [CrossRef] [PubMed]

24. Altobelli, E.; Rapacchietta, L.; Profeta, F.V.; Fagnano, R. HPV-vaccination and cancer cervical screening in 53 WHO European Countries: An update on prevention programs according to income level. Cancer Med. 2019, 8, 2524-2534. [CrossRef]

25. NHS Overview Abdominal Aortic Screening. Available online: https://www.nhs.uk/conditions/abdominal-aortic-aneurysmscreening/ (accessed on 1 November 2021).

26. Carnevale, M.L.; Koleilat, I.; Lipsitz, E.C.; Friedmann, P.; Indes, J.E. Extended screening guidelines for the diagnosis of abdominal aortic aneurysm. J. Vasc. Surg. 2020, 72, 1917-1926. [CrossRef] [PubMed]

27. Sweeting, M.; Thompson, S.G.; Brown, L.C.; Powell, J.T. Meta-analysis of individual patient data to examine factors affecting growth and rupture of small abdominal aortic aneurysms. Br. J. Surg. 2012, 99, 655-665. [CrossRef] [PubMed] 
28. Schmitz-Rixen, T.; Keese, M.; Hakimi, M.; Peters, A.; Böckler, D.; Nelson, K.; Grundmann, R.T. Ruptured abdominal aortic aneurysm-epidemiology, predisposing factors, and biology. Langenbecks Arch. Für Chir. 2016, 401, 275-288. [CrossRef]

29. Sampilvanjil, A.; Karasawa, T.; Yamada, N.; Komada, T.; Higashi, T.; Baatarjav, C.; Watanabe, S.; Kamata, R.; Ohno, N.; Takahashi, M. Cigarette smoke extract induces ferroptosis in vascular smooth muscle cells. Am. J. Physiol. Circ. Physiol. 2020, 318, H508-H518. [CrossRef]

30. Anzai, T. Inflammatory Mechanisms of Cardiovascular Remodeling. Circ. J. 2018, 82, 629-635. [CrossRef]

31. Cochrane, A.L. Effectiveness and Efficiency: Random Reflections on Health Services; Nuffield Provincial Hospitals Trust: London, UK, 1972.

32. Giardina, S.; Pane, B.; Spinella, G.; Cafueri, G.; Corbo, M.; Brasseur, P.; Orengo, G.; Palombo, D. An economic evaluation of an abdominal aortic aneurysm screening program in Italy. J. Vasc. Surg. 2011, 54, 938-946. [CrossRef]

33. Ying, A.J.; Affan, E.T. Abdominal Aortic Aneurysm Screening: A Systematic Review and Meta-analysis of Efficacy and Cost. Ann. Vasc. Surg. 2019, 54, 298-303. [CrossRef]

34. Agenzia Nazionale per i Servizi Sanitari Regionali (AGENAS), Piano Nazionale Esiti. Available online: https://pne.agenas.it/ (accessed on 22 October 2021).

35. Ashton, H.A.; Buxton, M.; Day, N.E.; Kim, L.G.; Marteau, T.M.; Scott, R.A.; Thompson, S.G.; Walker, N.M.; Multicentre Aneurysm Screening Study Group. The Multicentre Aneurysm Screening Study (MASS) into the effect of abdominal aortic aneurysm screening on mortality in men: A randomised controlled trial. Lancet 2002, 360, 1531-1539. [PubMed]

36. Nair, N.; Kvizhinadze, G.; Jones, G.T.; Rush, R.; Khashram, M.; Roake, J.; Blakely, A. Health gains, costs and cost-effectiveness of a population-based screening programme for abdominal aortic aneurysms. BJS 2019, 106, 1043-1054. [CrossRef] [PubMed]

37. Wild, J.; Stather, P.; Biancari, F.; Choke, E.; Earnshaw, J.; Grant, S.; Hafez, H.; Holdsworth, R.; Juvonen, T.; Lindholt, J.; et al. A Multicentre Observational Study of the Outcomes of Screening Detected Sub-aneurysmal Aortic Dilatation. Eur. J. Vasc. Endovasc. Surg. 2013, 45, 128-134. [CrossRef] [PubMed]

38. Altobelli, E.; Angeletti, P.M.; Rapacchietta, L.; Petrocelli, R. Overview of meta-analyses: The impact of dietary lifestyle on stroke risk. Int. J. Environ. Res. Public Health 2019, 16, 3582. [CrossRef] [PubMed] 